\title{
Maps: From Metaphor to Critical Topography'
}

DOl:70.18318/td.2015.en.2.3

\section{The Map, the Territory, and Deterritorialization}

Contemporary discussions on the meaning and functions of cartography mostly revolve around the relationship between the map and the territory. In spite of appearances, explanations of the issue are neither unambiguous nor obvious, and the relationship itself is so complex that it provides a more comprehensive look at the historically determined bond between culture and reality. This state of affairs stems from the fact that the map is currently one of the primary epistemological and ontological metaphors in philosophical, postcolonial, historical, and literary studies discourses. This, in turn, allows us to use it to comprehend the mutating conceptualizations of the link between representation and the world. Nevertheless, the map is not only a metaphor but also practice, an instrument of administration and an instrument of state applied to space and territory. We need to add, however, that it is a practice taken up not only by expert cartographers, but also by artists, writers, and other non-professionals. Finally, the map itself is

1 The article was developed as a part of a research project entitled Geopoetics. Places and Spaces in Contemporary Literary Theories and Practices, funded by the National Science Centre.

\section{Elżbieta Rybicka}

is a senior lecturer in Cultural Studies on the Faculty of Polish Studies at the Jagiellonian University. Her publications include The Forms of the Labyrinth in the Polish Prose in the Twentieth Century (2000), Modernizing the City: an Introduction to Urban Problematics in Modern Polish Literature (2003). and Geopoetics: Space and Place in Contemporary Theories and Literary Practices (2014). She specializes in cultural and literary geography, urban culture and cultural memory. 
a nomadic concept, circulating between academia (geographic cartography, history, art history, psychology, sociology) and artistic practice. It is a fairly broad, non-specific term, especially taking into account phenomena like thought maps, mind maps, gene and genetic maps, the latter including other genetic maps of Europe, biomapping, and rhizomapping. The nomadic character of the map as metaphor and as practice predicates a questions about its usefulness as an instrument of organizing knowledge as well as about its liminal placement in a field wherein visual, linguistic (including literary), geographic, and historic studies intersect.

The most striking characteristic of contemporary examinations of the map is the problematization of its capability to objectively represent geographic space. I wanted to highlight this problematization rather than reject representation because I believe that at least a couple of solutions exists. As noted by Peta Mitchel, ${ }^{2}$ the symbolic beginning of this problematization lies in Alfred Korzybski's famous premise that "a map is not the territory," ${ }^{3}$ formulated back in the 1930 s. I'd like to introduce a preliminary structure into the relationship between the map and the territory by appealing to three model situations and positions: the map-as-experiment that collaborates with the territory, the map-as-simulation devoid of territory, and the map producing the territory. This first way of understanding the map can be traced back to the rhizome theory and nomadology of Gilles Deleuze and Félix Guattari whose metaphoric thought model proposed a radical reformulation of the concept of the map. One of the principles of the rhizome (as an astructural, open model) is the principle of cartography which states that the map is not a tracing, but above all an area of experimentation:

Unlike the graphic arts, drawing, or photography, unlike tracings, the rhizome pertains to a map that must be produced, constructed in such a way that it is detachable, connectable, reversible, modifiable, and has multiple entryways and exits, as well as its own lines of escape. ${ }^{4}$

The map is open and connectable in all of its dimensions; it is detachable, reversible, susceptible to constant modification. It can be torn, reversed, adapted to any kind of mounting, reworked by an individual, group, or

2 Peta Mitchell, Cartographic Strategies of Postmodernity: the Figure of the Map in the Contemporary Theory and Fiction (New York: Routledge, 2008), 2-3. Alfred Korzybski, Science And Sanity (Lakeville: International Non-Aristotelian Library Pub. Co., 1958), 58 . 
social formation. It can be drawn on a wall, conceived of as a work of art, constructed as political action or as meditation. ${ }^{5}$

Contrary to conventional thinking, in Deleuze and Guattari's approach, the map does not fall within the scope of the optics of territory representation, but is rather considered experimental practice. In this case, it belongs to nomadic spatial logic, based on a sequence of transitions between deterritorialization and reterritorialization, on a state of openness wherein cartography is a process, and not an "image," a tracing or a visual reproduction. The original intention to problematize the map not as a creation - an object - but as a process, a mapping, corresponds to new directions in the theory of cartography. The map-as-experiment, however, does not break off its relationship with the territory as the primary principle of the rhizome is the principle of conjunction: as the rhizome acts in accord with the world, so does the map act in accord with the territory.

The second way of understanding the map is derived from the work of Jean Baudrillard, who opens one of his most famous texts with a reference to On the Exactitude of Science, a short story by Jose Louis Borges. The story then becomes a jumping-off point for his theory of simulation:

Today abstraction is no longer that of the map, the double, the mirror, or the concept. Simulation is no longer that of a territory, a referential being, or a substance. It is the generation by models of a real without origin or reality: a hyperreal. The territory no longer precedes the map, nor does it survive it. It is nevertheless the map that precedes the territory - precession of simulacra-that engenders the territory, and if one must return to the fable, today it is the territory whose shreds slowly rot across the extent of the map. It is the real, and not the map, whose vestiges persist here and there in the deserts that are no longer those of the Empire, but ours. ${ }^{6}$

In Baudrillard's allegoric narration the territory disappears while the mapas-simulation remains. Eventually, however, the map-as-simulation vanishes as well, as the atrophy of the territory inescapably results in the atrophy of the map.

Insofar as Baudrillard emphasized the map as pure simulation in which the reference to reality is dissolved, the contemporary critical examination of the map highlights, above all, its relationship with territory, accentuating not its

5 Ibid., 13 .

6 Jean Baudrillard, Simulacra and Simulation (Ann Arbor: University of Michigan Press, 1994), 1. 
capability to represent space but its creative capacity, its power to transform and create. ${ }^{7}$ This territorialism of the map stems from one fact that was suggestively emphasized by Karl Schlögel in his efforts to retrace the history of cartography:

Until it is measured and calculated, space is terrifying, wild, undisciplined, untamed, empty, and immeasurable. Only measured space becomes tame, explored, disciplined, sensible, it's forced to be practical. Only territorial space is capable of being ruled and ruling, it becomes the space of domination. ${ }^{8}$

This transmutation of space into territory intensified particularly in the Enlightenment era - that period saw the establishment of grand, long-term mapping projects looking to create detailed maps of France and England. The process of mapping the world coincided with the development of new tools and measuring instruments, the establishment of new institutions and ordinances standardizing systems of measurement. This dynamically developing "apparatus to measure the world" contributed, on one hand, to the creation of a modern, national, territorial state and the uniformity of territorial sovereignty in the spirit of Cartesian transparency; and on the other hand, entrenched the notion of the map as a cognitive instrument and metaphor for knowledge and cognitive processes. ${ }^{9}$

The relationship between the map and the territory manifests itself predominantly in the study of national identity and in postcolonial discourse. In this case, the map does not precede the territory, it produces it. In his Imagined Communities, Benedict Anderson considers the map one of three institutions of power, the other two being the census and the museum, that colonial powers used for years to imagine (and develop) their domains. ${ }^{10}$ The primary function of these institutions was to establish a totalizing classification grid that facilitated control and quantification. One classic example of such an effort was the Great Trigonometrical Survey of India - although that particular project also had economic motives.

7 For more insights on this see James Corner, "The Agency of Mapping: Speculation, Critique, and Invention" in Mappings, ed. Denis E. Cosgrove (London: Reaktion Books, 1999), 213-252.

8 Karl Schlögel, W przestrzeni czas czytamy. O historii, cywilizacji i geopolityce, trans. Izabela Drozdowska and Łukasz Musiał (Poznań: Wydawnic two Poznańskie, 2009), 164.

9 Ibid., 173

10 Benedict Anderson, Imagined Communities (London: Verso, 2006), 167. 
Anderson also points to two additional phenomena: firstly, the appearance of historical maps that legitimized antiquated delineations of territorial entities according to European notions of inheriting land. In other words, these maps established and legitimized borders not only in the present but also in the past. The other highly important issue was role of the "map-as-logo." It stemmed from the fact that imperial powers often marked their colonies on maps using the same colors they employed to represent the metropole:

Dyed this way, each colony appeared like a detachable piece of a jigsaw puzzle. As this "jigsaw" effect became normal, each "piece" could be wholly detached from its geographic context. In its final form all explanatory glosses could be summarily removed: lines of longitude and latitude, place names, signs for rivers, seas, and mountains, neighbors. Pure sign, no longer compass to the world. In this shape, the map entered an infinitely reproducible series, available for transfer to posters, official seals, letterheads, magazine and textbook covers, tablecloths, and hotel walls. Instantly recognizable, everywhere visible, the logo-map penetrated deep into the popular imagination, forming a powerful emblem for the anticolonial nationalisms being born. ${ }^{11}$

Naturally, the process of creating imagined relationships using cartography was reinforced by universal education, geographical and historical atlases as well as wall maps at school. What seemed unimaginable and inaccessible from a local perspective - like the entirety of the state (or empire) - was now clearly visualized in these resources. In this particular case, special emphasis was put on the performative qualities of the map as an instrument of building nations construed as "imagined communities" which considered territorial autonomy essential.

Another important issue that shines additional light on the relationship between word, map, and territory is the question of geographical onomastics. Conquest of space by means of cartographical grid involves not only quantification but also toponymy, and this particular issue is especially important to postcolonial studies. The toponymy of the "New World" was based on repetition, reproduction and multiplication with an element of differentiation. New Orleans, New York, New England, Nova Scotia became an extension of Europe, a mark of geographic continuity, and simultaneously a form of linguistic usurpation of territory. ${ }^{\mathbf{1 2}}$

11 Ibid., 179 .

12 Peter Jackson, Maps Of Meaning (London: Routledge, 1994), 167-169. 
The relationship between map and territory is also an important part of the study of national culture and processes that shape nations, thus becoming a constituent element of ideological geography. In the works of Zygmunt Wasilewski and Jan Ludwik Popławski, Eugenia Prokop-Janiec noticed the process of drawing up national maps which "divide - and order - the national cultural space, identifying areas, spheres, strips, islands, points of familiarity and otherness, areas that are culturally older and younger, pure and hybrid, nested and annexed or newly colonized, central and peripheral."13

The problems indicated here, related to the history of map as territorycreating instrument, are examined by critical cartography, a field developed in the early 1990 s by Denis Wood and Brian Harley; recent contributions to the field were made by Jeremy Crampton and John Krygier. Recognizing that maps "make reality as much as they represent it"14 is the basic premise of the field. Its primary objective is to draw attention to the close relationship of the map with Foucault's power/knowledge and to the significance of historical and geographical contexts to the development of cartography as both science and practice. The field is developing both in its theoretical aspect, as critical map theory, and its practical aspect, as alternative or subversive mapping. Critical cartography seems to be especially significant due to its meta placement with regard to traditional, institutional cartography, thus making it possible to examine and verify its scientific, ideological, military, and economic bases. Additionally, critical cartography informs us that aside from the map as a subject of scientific cartography and the map as an instrument of European cartographic reasoning, there exist alternative maps: of local cultures, artistic experiments, the results of psychogeographic mapping efforts of the Situationists, of cultural "hacking." Acknowledging the pluralism of maps shifts the distribution of cartographical knowledge: instead of being restricted to a small group of experts it is open to all. The import of critical cartography is linked with the recognition of the performative role of the map not only with regard to the transmutation of space into territory: "maps are active; they actively construct knowledge, they exercise power and they can be a powerful means of promoting social change." 15 As far as further development of critical cartography is concerned, Crampton and Krygier offer five possible areas of additional exploration: art; everyday mapping involving

13 Eugenia Prokop-Janiec, "Przestrzeń, mapa, geografia kultury narodowej, ${ }_{t}$ in Nacjonalizm polski do 1939 roku. Wizje kultury polskiej j europejskiej, ed. Krysztof Stępnik and Monika Gabryś (Lublin: Wydawnictwo Uniwersytetu Marii Curie-Skłodowskiej, 2011), 40.

14 Jeremy W. Crampton and John Krygier, "An Introduction to Critical Cartography," International E-journal for Critical Cartographies 4 (2005): 15

15 Ibid 
performative, indigenous, affective, and experiential elements; maps as resistance based on counter-mapping; map hacking; and theoretical critique.

Another interesting issue, aside from the problem of representation, revolves around the fact that the map combines visual, linguistic, and geographic codes. Therefore, as noted by Igor Piotrowski:

[...] we are dealing with an equilibrium of not two but three elements: words, imagery, and territory depicted on the map. All three elements are requisite for the map to come into existence and their homeostasis decides the sense of that semiophore. However, we should take note that this particular situation is exceptional. Other depictions do not feature similar correlations between image and text, their mutual complementation. Photographs or drawings can be meaningful even when not accompanied by descriptions or even a title. Without a legend, a map often becomes indecipherable. The same applies to territory, that is the designation of the map. [...] in the case of the map, unfamiliarity with the territory or incapability of properly locating it has immense influence over its comprehensibility. In other words: disruption of the harmonious coexistence of the three aforementioned elements results in a drastic decrease of the functionality of the map as signifying object or its transposition into another class of objects (images, text). ${ }^{16}$

Such an understanding of the map opens numerous avenues of inquiry at the intersection of literary studies, visual studies, and geography. We should also take note here that historians and theorists of cartography themselves have already emphasized the rhetorical character of the map. In critical cartography's early stages, J.B. Harley considered maps to be both cultural and rhetorical text and indicated that the procedures of their creation are rhetorical in character and are based on selection, simplification, classification, the creation of hierarchies, and "symbolization."17 Karl Schlögel also discussed cartographical narratives and the rhetoric of cartography. The relationship between maps, trajectories, and spatial stories was also emphasized by Michel de Certeau. ${ }^{18}$

16 Igor Piotrowski, "Słowo, obraz, terytorium. W stronę kulturowej analizy map, "in Słowo/obraz, ed. Iwona Kurz and Agnieszka Karpowicz (Warszawa: Wydawnictwo Uniwersytetu Warszawskiego, 2010), 130-131.

17 John Brian Harley, "Deconstructing the Map," Cartographica 2 (1989): 11

18 Michel de Certeau and Steven Rendall, The Practice Of Everyday Life (Berkeley: University of California Press, 2011), 115 
Therefore, in contemporary discourse the map has a somewhat paradoxical status: on the one hand, it is critiqued as the instrument of knowledge/ power, and on the other hand, it's appropriated by artistic, literary and other practices connected with the culture of resistance. It is also fairly easy to notice that nowadays the market for maps is booming, particularly due to the development of cybercartography. Peta Mitchell hypothesized that just as sun and light were primary metaphors for Enlightenment-era epistemes, and biological and mechanical tropes for the Modernist episteme, so the map is the key formative and performative metaphor for post-modernity. ${ }^{19}$ It is especially intriguing, given that the library and the labyrinth, both derived from the works of Borges, were the definitive metaphors of the late 2oth century. Is this transition, from the library and the labyrinth to the map, evidence of something aside from the obvious spatial turn? To attempt an answer to this question, I would like to first focus our attention on the matter of maps in literature.

\section{Literary Cartographies}

Starting with the assumption that a map is a liminal and nomadic phenomenon, a link between geography and other discourses, ${ }^{20}$ I would like to point out the functions it serves in literature and literary studies. And yes, firstly, it can be understood as metaphor or theme, sometimes as topos. Most often it is employed as a figuralization of the act of world creation (The Issa Valley by Czesław Miłosz is one example) or the exploration of unknown spaces (like in Joseph Conrad's The Heart of Darkness), historical events, and processes (as in Stefan Chwin's Biate kafelki, porcelana, nikiel). Maps portrayed in literature, especially recent literature, are also metaphoric sites of memory, a sort of mnemotopos reminding us of a certain area's past - like in the works of Pawel Huelle, Krzysztof Fedorowicz, and Henryk Wańka.

The map metaphor, however, can be understood in a broader sense, when the act of writing and creating fictional worlds itself is considered "a form of mapping or a cartographic activity."21 The writer, like the mapmaker, designs the spatial organization of the territory through selection, the establishment of scale and the limits of the depicted area, and emphasizing the importance of selected topographical elements. Such a narrative map of Dublin was

19 Mitchell, Strategies, 39

20 See Elżbieta Konończuk, "Mapa w interdyscyplinarnym dialogu geografii, historii i literatury," Teksty Drugie 5 (2011): 255-264

21 Robert T. Tally, Spatiality (London: Routledge, 2012), 45. see also Peter Turchi, Maps Of The Imagination (San Antonio: Trinity University Press, 2004). 
created by James Joyce in Ulysses, but Dante's Divine Comedy can also be read in this way - as an attempt to create an allegorical map.

Secondly, the map is often the subject of ekphrasis in the classic sense of the term - a linguistic representation of a visual representation. Naturally, ekphrasis introduces an additional layer of references as it evokes the problem of the relationship between word and visualization. Poem-maps, like Howard Howoritz's Wordmaps: Manhattan or Oregon Coast, are a separate issue arising at the intersection of literature, geography, and visual arts. This sort of visual poetry, as the author himself once noted, requires the reader to possess the knowledge of the geography and history of a given place, as it becomes entwined with the matter of the poetic text. ${ }^{22}$ Geographical space exists inside them simultaneously as visualization in the form of a map and as text. Therefore, in this particular case, we can say that there exists an equilibrium between word, image, and territory.

The map itself can also serve as the nucleus of a story, its point of origin. The most famous example of that is naturally R.L. Stevenson's Treasure Island, which begins with a map a father drew for his son. In Polish literature, examples of narratives that begin with maps include Kosmografia. Trzydzieści apokryfów tułaczych [Cosmography. Thirty Nomadic Apocrypha], Jacek Dehnel's series of miniatures, created for the 2012 exhibition in the National Library entitled The World of Ptolemy: Italian Renaissance Cartography in the Collections of the National Library. However, Dehnel's Apocrypha are not an illustration, not an attempt at translating the language of the map into the language of storytelling, but a narrative in which imagination plays a much greater role than the territory.

The map can also play a supportive role in the interpretation of literary texts. Vladimir Nabokov's Lectures on Literature feature his hand-drawn maps of England on which he marked the location where Mansfield Park takes place and the wanderings of Ulysses characters across Dublin. ${ }^{23}$ They are proof of the existence of a correlation between the creation of narrative maps and interpretative practice. Just as the creation of a fictional world can be compared to the mapping process - the creation of territories - the act of reading requires the readers to reconstruct or construct their own maps of the novel's territory.

The role of the map as an analytical instrument supporting the process of interpretation was emphasized especially by Franco Moretti. In his view, maps

22 Howard Horowitz, "Wordmaps" in GeoHumanities: Art, History, Text at the Edge of Place, ed. Michael Dear $r_{t}$ im Ketchum, Sarah Luria, and Doug Richardson (New York: Routledge, 2011), 107-111.

23 Vladimir Vladimirovich Nabokov and Fredson Bowers, Lectures On Literature (New York: Harcourt Brace Jovanovich, 1980), 10,334. 
can change the way a novel is read, accentuate specific geometries, boundaries, spatial taboos, and favorite routes. ${ }^{24}$ In Polish literary studies, Geografia Stowackiego [The Geography of Stowacki], a volume edited by Dorota Siwicka and Marta Zielińska, is a great example of utilizing the spectrum of possibilities offered by the map. ${ }^{25}$ Mikołaj Sokolowski examines the imagined geography and topographic inconsistencies of the poet, invoking medieval notions featured in ancient mappae mundi. Dorota Siwicka confronts the imaginary map of Słowacki's poems written in the early stages of the November Uprising with the real map of Europe. Monika Rudaś-Grodzka points out the importance of ancient maps to the geography of King Ghost. Michał Kuziak, in his interpretation of Salome's Silver Dream invokes maps drawn up by colonial powers. Marek Bieńczyk demonstrates the necessity of reflecting on the poet's biography in the analysis of the map depicting Słowacki's last voyage. Teresa Raczka uses hydrographic maps of the Black Sea watershed as a reference point for the poet's aquatic imagination. Given the nature of Słowacki's spatial imagination, freely combining imagination, phantasm, and real geographic locations, maps become a genuinely useful interpretative tool.

This methodology falls within the scope of literary cartography, a field which Barbara Piatti and Lorenzo Hurni, Swiss scholars involved with the Literary Atlas of Europe project, consider an auxiliary science or a subdiscipline of literary geography; its objective is to "translate" spatial elements of fiction into the language of cartographic symbols, thus facilitating new ways of reading and analyzing literature. ${ }^{\mathbf{2 6}}$ Most importantly, however, it is not about naive mapping that is unaware of methodologies or ignorant of differences. The metaphor of translation employed by the scholars introduces the essence of the issue fairly well, because it goes beyond the identity logic of the literary map and territory. The discrepancies and shifts between the narrative map and the real map seem to be the primary problem in this case. Just as the map is not the territory, the map of a fictional space is neither fiction nor territory, but to notice these differences one needs to confront both types of maps - real and fictional.

The Literary Atlas of Europe, ${ }^{27}$ created by literary scholars in collaboration with geography experts, opens a new chapter in the history of literary

24 Franco Moretti, Atlas Of The European Novel 1800-1900 (London: Verso, 1998), 3-5.

25 Geografia Słowackiego, ed. Dorota Siwicka and Marta Zielińska (Warszawa: Wydawnictwo IBL PAN, 2012).

26 Barbara Piatti and Lorenzo Hurni, "Editorial. Cartographies of Fictional Worlds," The Cartographic fournal 48 (2011): 218.

27 "A Literary Atlas of Europe," accessed February 11, 2013. http://www.literaturatlas.eu/?lang=en 
cartography, one directly related to the emergence and development of cybercartography and geographic information systems (GIS). For traditional literary geography, it is both a challenge and the subject of critique. Piatti and Hurni also indicate that literary scholars exhibit pronounced skepticism towards new methods of cartography that employ digital tools and instruments. First of all, there are fictional narratives that do not yield to mapping as they operate in universal spaces like "everywhere." Vanished places, especially in ancient literature, are also a serious challenge and call for expertise. ${ }^{28} \mathrm{Never}-$ theless, literary cartography, traditional as well as digital, has extensive cognitive benefits and advantages. Piatti and Hurni point out that, firstly, mapping can allow us to notice certain aspects of literature previously invisible; secondly, literary cartography allows us to fully grasp the cultural process of "the production of places," their meaning, function, and symbolic values. ${ }^{29} \mathrm{We}$ should also note that the emergence of literary cybercartography is a part of a broader process related to the development of new media, especially geomedia. Their increasing role and growing influence on both theory and cultural practice, as mentioned by Anna Nacher, indicates a "return to the positioning and concrete nature of real locations." ${ }^{30}$ That does not necessarily mean a return to purely empirical approach, as she later adds, but instead indicates the acknowledgement of a double hybridization and penetration, of place as cyber-place and media as locative media. ${ }^{31}$

Regardless of the possibilities, briefly presented here, in which the map may function in literature and literary studies, I would also like to examine whether the three previously mentioned models of the relationship between the map and the territory may be utilized in research praxis. Secondly, I would like to explore the matter of critical literary cartography. The first issue revolves around the question whether maps can exist without territory in literary worlds, as pure simulacra. In an attempt to answer that question, I would to bring up an example from the fantasy genre, the map from Terry Pratchett's Discworld, and thus a territory with a decidedly different ontology. My question is not intended to dissect the relationship between the map and the fictional territory, as the matter seems to be obvious and widely known, especially from J.R.R. Tolkien novels, and well covered by scholars. I am more interested in the relationship between the map of a fantasy world (as well as the narrative map of the depicted

28 Piatti and Hurni, "Editorial," 220

29 Ibid., 222

30 Anna Nacher, "Geomedia-między mediami a lokalizacją," accessed February 20, 2012. http:// www.scribd.com/doc/54125590/Geomedia-między-mediami-a-lokalizacją

31 Ibid 
world) and the geographical space of the real world. Stephen Briggs, the man responsible for the creation of the map of the Discworld released in a separate book, has described his work on the map of a fantasy space in this way:

I thought this was going to be easy.

It was the word 'fantasy' that led me astray. Tolkien and his descendants apart, fantasy landscapes are not known for the precise cartography. East of the Sun and West of the Moon is not a point on a map. Over the Hills and Far Away is not a recommended AA holiday route. [...]

In fact it took a lot more time than that...

I showed draft \# 1 to Terry, who looked at it for some time and said "Do you know what a rain shadow is?" This was new to me, who took Raffia instead of Geography. I was given a short lecture on mountain ranges and prevailing rain-bearing winds, which gently led up to the fact that I'd put the Great Nef, the driest place in the world, in what would have been a very large swamp. ${ }^{32}$

The procedure for creating fantasy maps is therefore bolstered by procedural elements for creating real-life maps. But that is not all. The same rules apply in the case of narrative maps of the depicted world. The world of Discworld is constructed out of elements rooted in the geographic spaces of the real word, as well as fairytale and imagined geographies. The reader of Pratchett's novels should, therefore, possess actual knowledge about current and historical geography, the latter pertaining to ancient and medieval concepts and notions. Both Pratchett and his readers live in a world defined by real-world geographical formulas and - we may even say - cartographic understanding which, obviously, does not preclude engaging in intertextual and parodistic games with these formulas.

Can narrative maps create territory? Put more forcefully, can they influence empirical spaces? History knows such incidents, with one of them being the change of the name of the French town Illiers, where Marcel Proust used to vacation as a child, to Illiers-Combray. ${ }^{33}$ Another is Thomas Hardy's fictional area of Wessex, its names and places still in use by people living in southwestern England. ${ }^{\mathbf{3 4}}$ The latter example proves that narrative maps mold

32 Stephen Briggs, "Many Miles Across Tortuous Terrain," in Terry Pratchett and Stephen Briggs, Discworld Mapp (London: Corgi, 1995), 6.

33 See Donald Heiney, "Illiers And Combray: A Study In Literary Geography," Twentieth Century Literature, 1 (1955): 17-26.

34 Malcolm Bradbury, Atlas literatury [The Atlas of Literature], trans. Anna Błasiak, Dorota Gostyńska, Magdalena Jędrzejak, Iwona Libucha (Warszawa: Prószyński iS-ka, 2002), 135-138. 
the mental maps of the readers themselves, shaping their idea of the territory. In consequence, neutral locations and spaces become important topographical sites, recognizable thanks to literature.

Another issue revolves around the question whether we can, and if so then in what way, apply inspirations evoked by critical cartography in literary or cultural studies. Let me bring up an example. Jon Hegglund, a scholar of modernist literature, used the premise of critical cartography to design a research project on the rhetoric of cartography in James Joyce's Ulysses. ${ }^{35}$ Hegglund points out that the map Joyce used was created by the imperial administration, and thus the book touches on the subject of English-Irish relations. Nevertheless, Hegglund adds that the spatial complexity of the novel cannot be simply reduced either to imperial domination or postcolonial nationalist resistance. In Ulysses, the static map is confronted with a dynamic narrative - order imposed administratively from above is confronted with local, grassroots transformations. In the words of Michel de Certeau, strategies are confronted with tactics.

Critical functions of literary maps can be discharged in a variety of ways. Firstly, literature can reveal the limitations of cartography and the map in a discursive way, by formulating and designing interpretations or putting new questions forward. One clear example of that approach can be found in the last poem of Wisława Szymborska, Map, which - in spite of appearances - is not ekphrasitic, but rather a discursive contemplation of the prototype map:

Everything here is small, near, accessible.

I can press volcanoes with my fingertip, stroke the poles without thick mittens,

I can with a single glance encompass every desert with the river lying just beside it.

A few trees stand for ancient forests, you couldn't lose your way among them.

$[\ldots]$

Mass graves and sudden ruins are out of the picture.

Nations' borders are barely visible as if they wavered - to be or not.

35 Jon Hegglund, "Ulysses and the Rhetoric of Cartography," Twentieth Century Literature 49, 2 (2003): 164-192. 
I like maps, because they lie.

Because they give no access to the vicious truth.

Because great-heartedly, good-naturedly

they spread before me a world

not of this world. ${ }^{36}$

Literature may reveal problems related to the map in a way that is less literal and more graphic, metaphoric or allegoric. This approach is employed by Jacek Dehnel in his aforementioned volume. Tactics derived from the logic of the absurd can also be applied. As an example, I would like to juxtapose in a sort of thought experiment - two passages. One is a quote from an 1899 article written by Jan Ludwik Popławski:

A map of the future Anglo-African state was released over a dozen years ago.It featured [...] borders, cities, railways that had yet to be built. With each passing year, the borders and the state of English possessions in Africa creep ever closer to that idealized outline drafted all those years ago. ${ }^{37}$

The second passage is a quote from Alphabetical Africa, an experimental novel by Walter Abish:

On the maps Tanzania is colored a bright orange. Neighboring Malawi is light blue. The maps are the key to our future prosperity. [...] Each day one hundred thousand Tanzanians carrying ladders, buckets of orange paint and brushes, are driven and also flown to different sections of the country. They paint everything in sight. [...] The Queen also proudly explains that Malawi has also decided to conform to international mapping standards, and since Tanzania had a technological headstart, she could export a light blue paint to Malawi. ${ }^{38}$

Therefore, colonial production of territory is more than just an imaginary practice or a product of contemporary theories, and in Abish's novel it becomes an exaggerated, cartoonish illustration of European "mapping standards."

36 Wisława Szymborska, "Map," trans. Clare Cavanagh, New Yorker, accessed 10 June 2016,

http://www.newyorker.com/magazine/2014/04/14/map

37 Jan Ludwik Popławski, "Realizm polityczny i przyszła Polska," as quoted in Eugenia Prokop-Janiec, "Przestrzeń," 42

38 Walter Abish, Alphabetical Africa (New York: New Directions Publ. Corp., 1974), 53 
The critical potential is eagerly activated especially in contexts linked with the politics of place, in areas where there is tension between the official map as the symbol of the authorities' power over the space and the local perspective. Such a local, slightly grotesque perspective was featured by Leon Bielas in the Silesian novel Stawna jak Sarajewo [Famous Like Sarajevo]:

A torn up map of Poland lay on the floor. Manek knew it well. The responsibilities of the student on duty included hanging the map up before geography classes. It had a flaw before: "Konewka" was nowhere to be found on the map, but Manek took care of that. The story was that the map was created far away from here and, naturally, by adults. And adults, as everyone knows so well, are absent-minded. So they forgot to put Konewka on the map. Manek called Selwik up to bring him some red ink and they drew the missing town onto the greenish sheet. They wrote the name in in huge letters so that even the kids in the last row would see it, the lines straight like the bridge over the Przemsza, blocking out the Krakow-Katowice rail line. ${ }^{39}$

Lastly, we will examine the matter of the map-experiment but it deserves a separate inquiry.

\section{Map of the Niewiadomskiland}

Andrzej Niewiadomski's Mapa.Prolegomena [Map. Prolegomena] requires two different readings: a visual reading, pertaining to the map, and a linguistic reading. The former is initiated by the map that simultaneously functions as the book's cover. It is a map of a very peculiar sort - it is basically devoid of proper names (aside from a couple of local microtoponyms and an abbreviation "S." located next to a town), road numbers, it lacks a legend, and has no signals that would allow us to associate it with a particular territory. At first glance, it is an indecipherable map without a territory, map of the space of the unknown, the Niewiadomskiland [the author's last name, "Niewiadomski," is a development of "niewiadomy," Polish for "unknown" - ed.] The starting point for the other, textual, linguistic reading of the book is its title and the opening lines. The distinction is obvious but I wanted to highlight it as the relationship between the title and the opening lines is built on tension. Prolegomena suggest a genre framework appropriate for non-fiction content, for scientific or philosophical discourse. The book opens with negative definitions that essentially do not question that framework: "The map is not 
an objective, not a myth, it is neither speculation nor game, it is neither of these terms exclusively, nor is it their sum."40 It quickly launches into conditional mode and develops a couple of potential openings using pastiche-like stylizations:

If it were so, we could begin like this: "There it was, in my nearly forgotten childhood, on the desk, in a room whose walls rendered themselves far away, as far as the horizon and I, intoxicated, leafed through its pages, the sheets burning with vivid color, toying with the sweet promise of the summer haze." Or like this: "There were once two maps, great maps of continents and oceans, their incompetent imitation of similarity, the weathered sheet depicting a state that no longer exists, the names barely visible, a sheet over which the spectre of destruction has hung since time immemorial." Another opening: "In order to exist, a map only has to have the potential to exist, for example, no map is simultaneously a handrail, although there are maps that contradict that statement and claim otherwise, as well as maps looking quite like a handrail." And another one: "We can assert that in modern times writing about a map is basically impossible and then casually draft an amazing piece and pass ourselves off as the last essayist cartographers in the world."41

This opening suggests that we should pay equal attention to what Niewiadomski says about the map in a discursive manner as well as the language he uses and the way he uses it. The method which he uses to construct the text becomes a critical instrument with which to examine the definition and definability of maps. Secondly, the possibility category, revealed in the variety of openings and the introduction of a hypothetical mode, is also key in this instance. There is an additional third issue: genre instability or inconsistency. Further reading introduces additional complications, as autobiography mixes with fiction and literary criticism. I focused on the issue of the genology of Niewiadomski's book because it seems that finding the answer to the question of what genre are we ultimately dealing with should be absolutely fundamental. Naturally, the contemporary essay incorporates all of the abovementioned genre conventions, thus destabilizing reading norms, but Niewiadomski's book refers to a very specific field of reference - the essayistic work of Robert Musil. The first chapter features characters whose names seem drawn

40 Andrzej Niewiadomski, Mapa. Prolegomena (Lublin: Ośrodek "Brama Grodzka-Teatr NN," 2012), 7 .

41 Ibid. $7-8$. 
from The Man Without Qualities: Bonadea, Diotima, Agathe. The narrator himself claims that back in school the children used to call him little Ulrich. ${ }^{42}$ And lastly is the ostentatious conditional mode, a speculative formula signaling capacities introduced right from the start. Employing a broad understanding of essayism will be crucial here - an interpretation that considers it as a means of expression spanning scientific and literary discourse, and as an attitude aimed at assuming multiple perspectives, at indeterminateness and the sphere of potentiality; it is also an attempt to frame life itself or, finally, as going astray on an adventure. ${ }^{43}$

Potentiality as the key category of essayism is also related to the geography of the essay - maps produced and described by Niewiadomski. The book features numerous toponyms - authentic and recognizable, but also fake, codenamed, encrypted, displaced. Why does the author use the letter "H.," an abbreviation of the pre-war German name of the town, instead of using "L.W."? The latter may have been too obvious a trope, one that would lead too quickly to the rhetoric of locality and "small homelands," and that rhetoric is a negative field of reference. In any case, toponymy becomes an experimental field which problematizes their localization function. Is this the "atopical topography" that John Hillis Miller writes about in his discussions of the poetry of Wallace Stevens? ${ }^{44}$ In any case, experiments conducted on toponyms may signal something else. One recurring experiment seems to be especially characteristic - Niewiadomskiland. It is both a town in the pre-war Vilnius voivodeship, for which the book provides precise geographic coordinates: " $55^{\circ} 17^{\prime}$ north and $27^{\circ} 15^{\prime}$ east. On the most precise of maps." 45 It can be found on pre-war military maps. Nevertheless, Niewiadomskiland functions within the essay also as a polysemic neologism: the "land of the unknown [as per the explanation of the author's name provided above -ed.]" and a somewhat biographic "land of Niewiadomski," of poet, essayist, literary critic and historian, because "biography is part of the map." 46 Finally, as these connotations should come to mind in this case, it is the land of language that, unlike Polish, remains impenetrable and unpredictable. Geography, cartography, biography, language, and imagination intersect in one single toponym to create

42 Ibid., 12.

Robert Musil, The Man Without Qualities (New York: Alfred A. Knopf, 1995), 1:273.

44 John Hillis Miller, Topographies (Stanford: Stanford University Press, 1995), 258.

45 Niewiadomski, Mapa, 89

46 Andrzej Niewiadomski, "Biografia jest częściq mapy. Z Andrzejem Niewiadomskim rozmawia MichałLarek." Interview by Michał Larek. Studium 2 (2005): 44. 
a toponomastic trope ${ }^{\mathbf{4 7}}$ founded on the rule of syllepsis. ${ }^{\mathbf{4 8}}$ Niewiadomskiland - as a toponomastic trope - has to be read in two ways simultaneously, as the proper name of a real location (and its linguistic trace in the text) and as fiction, according to the precepts of literary poiesis. Syllepsis, therefore, leads us into an area comprising the nexus of the real and the imagined, which allows it to codename the primary rule of geopoetics-the span between two opposite notions, "geo" and poiesis. It is about maintaining equilibrium and preserving the tension between the subject (biography), reality (geography), and language (poetry, imagination) without dismissing any of the three elements of this dynamic configuration and simultaneously retaining the undeterminable potentiality that suspends the choice of only one option.

I would like to derive one general conclusion from this sylleptic toponomastic trope, a conclusion pertaining to the status of geographic space in the essay. It takes the form of a territory "without qualities"-a designation introduced by Andrzej Niewiadomski in his examination of the rules shaping Andrzej Sosnowski's poetry. ${ }^{49}$ It is a direct reference to The Man Without Qualities but, just like in Musil's work, it does not denote territory lacking identity. Its primary characteristic is the suspension and blurring of boundaries:

It is about space being organized in a way that not so much abides by contradictions as "plays" them and obscures their boundaries, creating an alternative that is impossible to precisely define (or is defined differently each time) and one that exists outside of them. [...] As we face a world without a designation and a world filled with an overabundance of designations, we find ourselves at a loss to say anything certain about it. ${ }^{50}$

This method of producing space is also a reference to Musil's Vienna, depicted as a space of potentiality suspended between a real and an indeterminate city.

47 See Janusz Hurnik, "Funkcje tropów toponomastycznych w liryce Tadeusza Różewicza," in: Onomastyka literacka, ed. Maria Biolik (Olsztyn: Wydawnictwa WSP, 1993), 237-244.

48 For syllepsis see: Ryszard Nycz, "Tropy «ja». Koncepcje podmiotowości w literaturze polskiej ostatniego stulecia," in: /ęzyk modernizmu. Prolegomena historycznoliterackie, ed. Ryszard Nycz (Wrocław: Wydawnictwo Leopoldinum, 1997), 107-109.

49 Andrzej Niewiadomski, "Poezja niezrozumiała, czyli o nadzwyczaj trwałym nieporozumieniu krytycznym. Rekonesans badawczy," Teksty Drugie 4 (2004): 141

50 Ibid. 
The rule of potentiality applies also to the case of map-as-cover. As I already mentioned, at first glance the map seems to lack territory but the last chapter of the essay features a depiction of the journey to $S$. which allows us to decipher both the place and the area. Therefore, the map which opens the book can function both as a map of the "unknown," without references to a concrete, real territory, but also as a map-as-experiment in conjunction with the territory. Its experimental character stems from the fact that it was stripped of proper names and tampered with in other ways. It resembles the "incorrect" map of the world created by the Surrealists in 1929, one of the first examples of critical cartography, critiquing Eurocentrism and the cartographic logic of representation. Similar endeavors can be read as mismapping, but they are more than just a hoax: they are more of a misreading. Just as misreading precludes the possibility of proper interpretation, so does mismapping preclude the possibility of properly deciphering the map featured on the cover. The reader can conclude that the map is a representation of a territory and look for its real-life counterpart, as well as perceive it as a map outlining a journey, an encrypted map which, like in The Hobbit, requires insight into encoding procedures that were used. In a strategy that is equally promising, the reader can inquire into the purpose and significance of the mismapping and the absence of toponyms. In any case, once again the openness to potentiality and multiple possible readings seems to be crucial. Niewiadomski's essay not only discusses cartographic and literary maps, it also experiments with them, problematizes the precept of directly referencing real-life locations without invalidating it. The map and the Map are suspended between representing real territory, producing new territory ("the Niewiadomskiland") and experimental mismapping of territory. These "faults," however, including all deviations, deformations, deficiencies, are impossible to notice if not confronted with the prototype map or the territory itself. The "incorrect" map, however, always invokes the "correct" original. In other words, it lays out the movement pattern between deterritorialization and reterritorialization.

Niewiadomski's essay is an experimental attempt at formulating a theory and critique of the map, between scientific and literary discourse, as it confronts cartography as a branch of science with poetic cartographical imagination. We can say that it acts on the basis established by a cartography of the rhizome, a thought experiment, and the principle of conjunction. However, I would see the critical nature of Niewiadomski's Map applied elsewhere-in the critique of the understanding of map as a representation of a geographical space and the simultaneous critique of the map as pure simulation, separate from reality. We are left with another solution - an experimental map as a non-definite potentiality, suspended between deterritorialization and reterritorialization, between "geo" and poiesis. 


\section{On the Benefits of Maps}

In essence, Borges's allegoric narrative tells us about the collapse of cartographic reason, failure of the effort to represent the world on a map scaled "mile to the mile." The issue was also discussed by Umberto Eco in his essay On the Impossibility of Drawing a Map of the Empire on a Scale of 1 to $1 . .^{51}$ In spite of the logic of the absurd employed by Eco, this short text is an excellent critique of the utopia of cartographic representation. The contemporary justification for maps should probably be sought elsewhere. Chapter 83 of Eco's Foucault's Pendulum, dealing with a variety of mistaken maps, opens with the aforementioned quote from Korzybski and concludes with the following dialogue:

"It was not to discover the 'true' form of the earth, but to reconstruct, among all the mistaken maps, the one right map, the one of use to him." "Not bad, not bad at all," Diotallevi said. "To arrive at the truth through the painstaking reconstruction of a false text." 52

Unfortunately, Korzybski's premise functions in mass consciousness in its abbreviated form, whereas the full quote is much more illuminating: "A map is not the territory it represents, but, if correct, it has a similar structure to the territory, which accounts for its usefulness." Borges, Korzybski, and Eco all emphasize the pragmatic nature of the map and its usefulness, and in such a situation the problem of map as representation essentially becomes secondary. From this perspective, even the "mistaken" fictional narrative maps can turn out to be useful, providing avenues of interpretation, revealing locations, imbuing them with specific sense, reevaluating their petrified meanings, evoking forgotten histories of specific areas, creating mental maps and countermaps, and providing orientation in space.

Translation: Jan Szelagiewicz

51 Umberto Eco, "On the Impossibility of Drawing a Map of the Empire on a Scale of 1 to 1, " in How to Travel with a Salmon and Other Essays (New York: Harcourt, 1994), 95. 